\title{
PHENOLOGICAL STUDIES IN AUSTRALIA: POTENTIAL APPLICATION IN HISTORICAL AND FUTURE CLIMATE ANALYSIS
}

\author{
MARIE R. KEATLEY, a,b, $*$ TIM D. FLETCHER, ${ }^{\mathrm{c}}$ IRENE L. HUDSON ${ }^{\mathrm{d}}$ and PETER K. ADES \\ ${ }^{a}$ School of Resource Management, University of Melbourne, Creswick, Australia \\ ${ }^{\mathrm{b}}$ School of Science \& Engineering, University of Ballarat, Mt Helen, Australia \\ ${ }^{c}$ Department of Civil Engineering, Monash University, Clayton, Australia \\ ${ }^{\mathrm{d}}$ Department of Mathematics and Statistics, Canterbury University, Canterbury, New Zealand \\ e School of Resource Management, University of Melbourne, Parkville, Australia \\ Received 8 February 2002 \\ Revised 16 April 2002 \\ Accepted 17 June 2002
}

\begin{abstract}
Phenological observations of eucalypts (Myrtaceae) were undertaken in four Australian states (New South Wales, Queensland, Victoria, and Western Australia) from the late 1920s until the early 1980s, by the respective State Forest Commissions. Unfortunately, few records have survived. For Victoria, surviving records encompass 42 forest districts, covering from less than 2 years to 42 years, and approximately 50 species.

This paper concentrates on the flowering of four competing species (Eucalyptus leucoxylon, E. microcarpa, E. polyanthemos, and E. tricarpa) over 23 years (1940-62) from Maryborough, Victoria, recorded on a monthly basis by one observer over the period. This study represents one of the first attempts to utilize Australian phenological data to detect responses to climate change.

There were no significant trends $(P=0.05)$ over time in the mean flowering commencement date. Forward stepwise regression found a significant relationship between temperature and flowering commencement in two species (E. leucoxylon: $R^{2}=0.42, P<0.01 ; E$. polyanthemos: $R^{2}=0.47, P=0.02$ ). Rainfall also had a significant influence on flowering commencement in $E$. tricarpa $\left(R^{2}=0.60, P<0.01\right)$, E. leucoxylon $\left(R^{2}=0.43, P=0.02\right)$ and $E$. polyanthemos $\left(R^{2}=0.24, P<0.01\right)$. The combination of temperature and rainfall (with temperature exerting the greatest influence), however, was significant for all species and had the most explanatory power (ranging from $R^{2}=0.74$ to 0.85 , $P<0.01)$.

Overall, in response to predicted increases in temperature and summer rainfall, E. leucoxylon and E. tricarpa would commence flowering later. In E. polyanthemos and E. microcarpa, increased temperature and rainfall will result in an earlier onset of flowering. Copyright (C) 2002 Royal Meteorological Society.
\end{abstract}

KEY WORDS: phenological studies; indicator species; eucalypts; climate change

\section{INTRODUCTION}

Phenological study involves the recording of recurring natural events such as the commencement of flowering (Keatley et al., 1999; Koch, 2000) or the arrival of migratory birds (Sparks, 1999), and the influence on such events by edaphic and climatic factors (Leith, 1974). Along with other forms of long-term monitoring, however, phenology has often suffered from the view that the work is not 'real science' (Findlay and Jones, 1989; Sparks et al., 2000).

Recent analyses of phenological data, which have been used to examine potential impacts of climate change and the observed global increase in temperature (IPCC, 2001a), are changing this perception (Schwartz, 2000; Sagarin and Micheli, 2001; Whitfield, 2001). Phenological studies have demonstrated the impacts of climate

* Correspondence to: Marie R. Keatley, School of Resource Management, Institute of Land and Food Resources, University of Melbourne, Water St., Creswick, Victoria, Australia, 3363; e-mail: mrk@unimelb.edu.au 
change on biodiversity, agriculture, and forestry (e.g. causing the disturbance of flowering cycles of plants) (IPCC, 2001b).

These studies, however, have thus far used data concentrated in the Northern Hemisphere. The majority of studies have used data covering 20 years or more (Manning and Nobre, 2001), necessitated by the inherent noise in these data sets (Menzel et al., 2001).

\subsection{Overview of phytophenological studies in Australia}

Indications are that long-term phenological studies within any discipline are extremely limited in Australia (Manning and Nobre, 2001). The extent and availability of phytophenological records are largely unknown, as there is not a coordinated approach to their compilation, storage, and reporting. Datasets spanning a century or more, such as are found in Europe (Sparks and Carey, 1995; Ahas, 1999), are unlikely in Australia, given the short period of European settlement (e.g. since 1788 for Sydney, and since 1835 for Melbourne).

Eucalypts form the focus of known Australian phytophenological studies, as they are the dominant species both in a botanical and economic sense (Boland et al., 1984). By 1893, the 'vagaries' of Eucalyptus flowering had been recognized and published in the second edition of The Colonial Beekeeper (Chambers, 1893). Between 1905 and 1921, information on the approximate flowering times for eucalypts was published in apiary journals (McLachlan, 1909, 1921).

Forest Commissions undertook monitoring of the reproductive phenology of eucalypts in four Australian States (New South Wales, Queensland, Victoria, and Western Australia) over varying periods, from 1925 to 1981. The primary aim was to understand the production of seed for regeneration after harvesting; but, to do so, there was a requirement to understand the whole reproductive cycle, commencing with bud development. The duration of surviving observations varies significantly within and between the States. In Victoria, where this study is based, the datasets range in length from 2 to 42 years, and encompass 50 species.

Currently, there are limited phenological studies undertaken at a research level in Australia (Pook, 1997; Keatley, 1999; Law et al., 2000). These are representative of the type of study being funded - short term (10 years or less) and focused mainly on commercial species.

\subsection{Objectives}

This paper has two objectives:

1. To examine the flowering of four competing species and determine whether there has been a change in flowering commencement date over time (1940-62).

2. To determine whether there is a relationship between flowering commencement date and climate (temperature and rainfall).

The impact of climate change in the region of study includes a predicted increase in annual average temperature of approximately $1{ }^{\circ} \mathrm{C}$ (predicted range of 0.4 to $1.3{ }^{\circ} \mathrm{C}$ ) by $2030(\mathrm{CSIRO}, 2001)$ ). A $5 \%$ (predicted range of 0 to $10 \%$ ) increase in rainfall per $1{ }^{\circ} \mathrm{C}$ global temperature increase is predicted for the warmer months (November to April) (Whetton et al., 1996). In the winter months (May to October), the predicted rainfall change ranges from -5 to $+5 \%$, and so the midpoint of $0 \%$ (no change) has been assumed. Given these general trends, the analyses will examine likely scenarios for changes ('shifts') in flowering commencement.

\section{DATA AND METHODS}

\subsection{Phenological data}

The records used in this study come from Victoria and are the field data of a Forest Overseer, Mr Bill Sheen, who worked in the Maryborough district (see Figure 1) between 1934 and 1962.

The surviving records cover the period from 1940-62. It is evident from notes in Sheen's field diaries that records commenced earlier. These records, however, have been lost. Whilst there are also records from 1962 


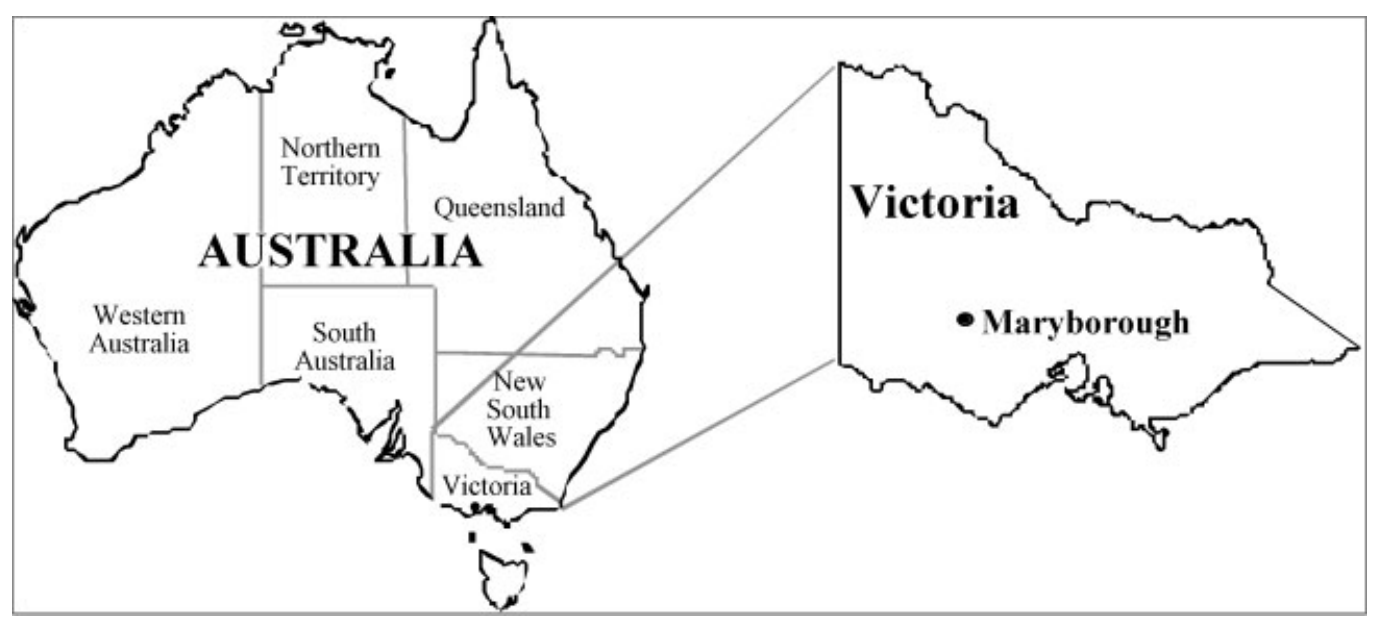

Figure 1. Study site location

to 1978 , these were recorded by another observer. Analysis of the data shows that interpretation of intensity and distribution of flowering differed between observers (Wells, 2000). These records have therefore not been included in this study.

Sheen reported the timing and distribution of flowering and budding of eight species. The observations were undertaken on a regular basis, on the 15th (and sometimes 16th) of each month. Whilst the monthly basis of the data limits the sensitivity of the analysis, no data of greater temporal resolution are known to be available in Australia. It should also be noted that the mean flowering for each of the species studied is greater than 3 months. Observations were undertaken within plots. This study concentrates only on the four species that commonly occur together (Muir et al., 1995):

- Eucalyptus leucoxylon - yellow gum (YG)

- E. microcarpa - grey box (GB)

- E. polyanthemos - red box $(\mathrm{ReB})$

- E. tricarpa - red ironbark (RIB).

\subsection{Climatic data}

Daily rainfall and daily minimum and maximum temperature records were obtained from the Bureau of Meteorology for the closest weather station (approximately $3.5 \mathrm{~km}$ away): Maryborough, Victoria $\left(37^{\circ} 03^{\prime} \mathrm{S}\right.$, $143^{\circ} 44^{\prime} \mathrm{E}, 249.3 \mathrm{~m}$ elevation). The temperature dataset had some missing data. When only one day was missing, the average of the temperature either side of the missing date was used. If two or more days were not recorded, then the mean minimum or maximum temperature for that month was substituted.

The primary subject of this study is the relationship between flowering commencement date and temperature, since temperature is a major climatic influence on phenological events such as flowering (Schwartz, 2000; Snyder et al., 2001). The study area, however, experiences mean annual areal potential evapotranspiration significantly in excess of mean annual rainfall, and so the influence of rainfall has also been examined, both alone, and in combination with temperature.

Mean areal potential evapotranspiration was derived from Wang et al. (2001). These data, along with the mean monthly rainfall and the minimum and maximum temperatures, are illustrated in Figure 2.

Figures 3 and 4 show the long-term climatic data for the study site, between 1939 and 2001. Figure 3 presents the deviation between annual mean daily temperature and the long-term mean for annual mean daily temperature over this period. Figure 4 presents the deviation between annual rainfall and the mean annual rainfall for the same period. The study period is identified by a dashed box in each figure, and includes the year 1939 (1 year before the flowering data commence), to encompass climatic influences up to 12 months 


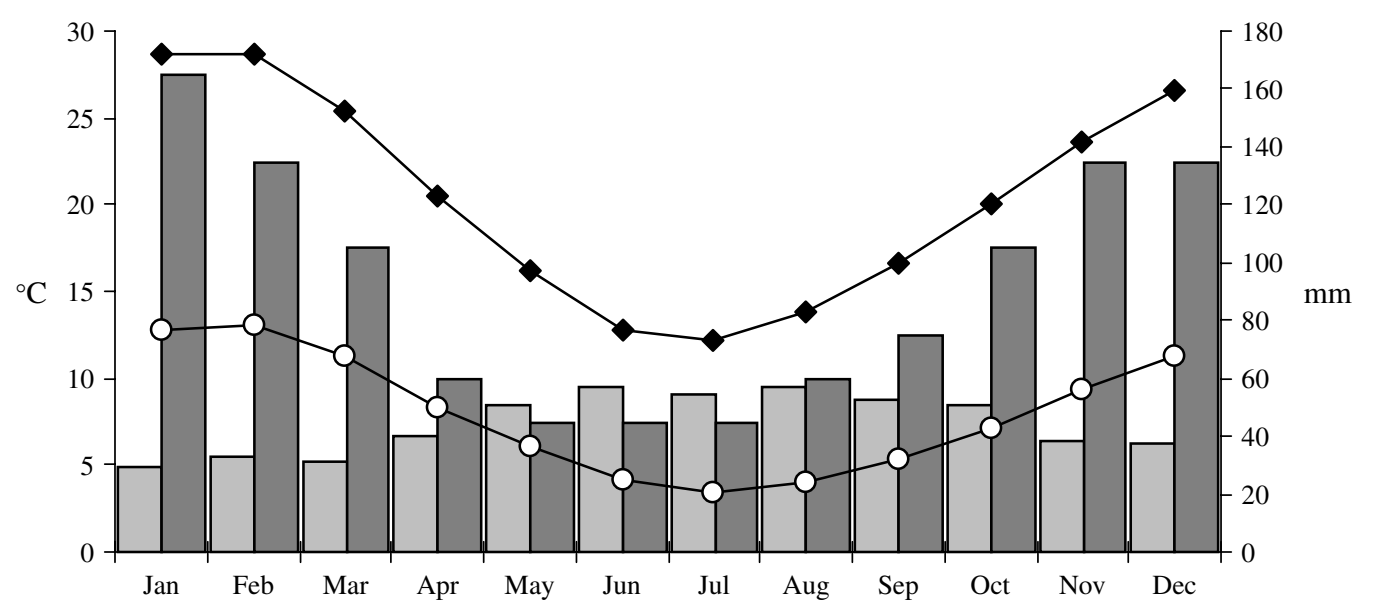

\begin{tabular}{ll|}
$\square$ Mean Monthly Rainfall $(\mathrm{mm})$ & $\square$ Mean Areal Potential Evapotranspiration \\
$\square-$ Mean Maximum Temperature $\left({ }^{\circ} \mathrm{C}\right)$ & $-\mathrm{O}$ Mean Minimum Temperature $\left({ }^{\circ} \mathrm{C}\right)$ \\
\hline
\end{tabular}

Figure 2. Mean monthly rainfall, minimum and maximum temperatures, as well as mean areal potential evapotranspiration

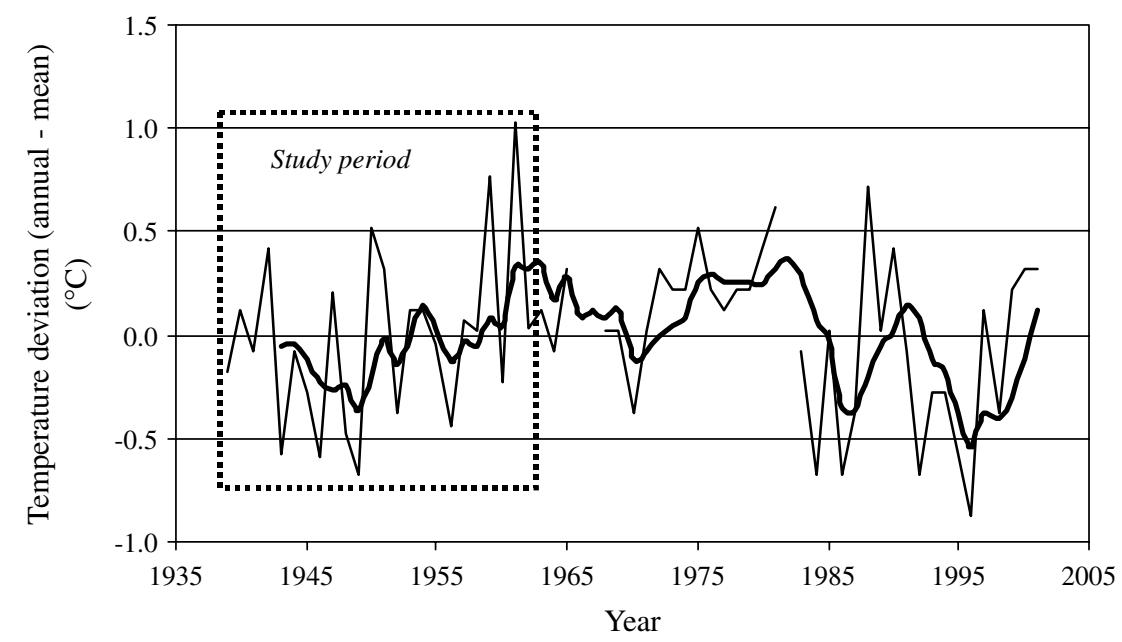

Figure 3. Deviation of annual mean daily temperature from long-term (1939-2001) mean of annual daily temperature (heavy line shows 5 year moving average). Gaps represent years with significant missing data

prior to flowering. Linear regressions for the temperature and rainfall data over the period from 1939 to 2001 show no significant trends $(P=0.90$ and $P=0.27$ for temperature and rainfall respectively). For the study period (1939 to 1962) considered in isolation, there appear to be very weak increasing trends in temperature $\left(R^{2}=0.06, P=0.13\right)$ and rainfall $\left(R^{2}=0.10, P=0.07\right)$.

\subsection{Analysis methods}

The annual average flowering commencement date (commencement of flowering is defined by the presence of open flowers in the crown) was calculated for each species. The average daily temperature for each month and total rainfall for each month were calculated, for the 12 months prior to the average flowering commencement date. Eucalypt flower buds may develop over at least 12 months (Davis, 1969; Loneragan, 


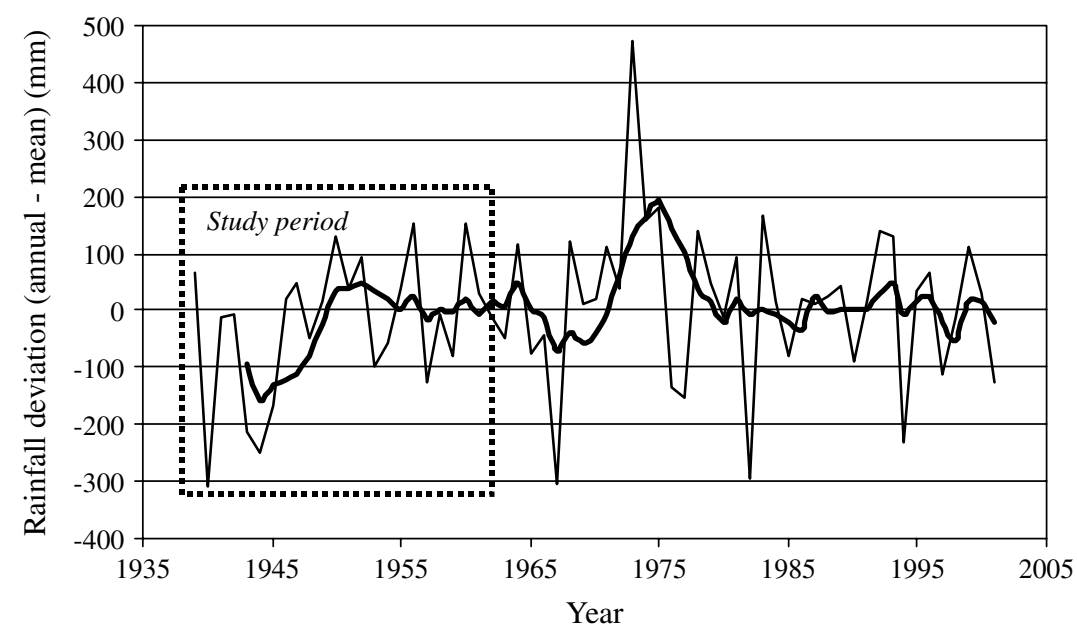

Figure 4. Deviation of annual rainfall from long-term (1939-2001) mean of annual rainfall (heavy line shows 5 year moving average)

1979; Moncur and Boland, 1989), meaning that climatic conditions over this period may have an influence on the commencement date of flowering. Consequently, incorporation of 12 months of climate data are required (3, 6 and 9 months prior were also examined, but were found to have less descriptive power).

Stepwise forward regression and simple linear regression were then used to examine the relationships between the date of commencement of flowering and the climatic data.

\section{RESULTS}

\subsection{Flowering over time}

Figure 5 shows the variation in flowering commencement date between 1940 and 1962, for all four species. E. polyanthemos (mean flowering commencement day \pm std dev. $=$ Julian day $286.7 \pm 48.6$ ) and E. tricarpa $(99.4 \pm 53.1)$ show no real change in flowering commencement date over the 23 years. Whilst it appears that over this time frame that E. leucoxylon (mean: $133.7 \pm 51.3$ ) flowering has commenced later and $E$. microcarpa $(47.9 \pm 28.9)$ has started flowering earlier, both series are influenced by individual points which exhibit substantial leverage on the trend. None of these linear trends is significant at $P=0.05$.

It should be noted that flowering in E. leucoxylon lasted for longer than 12 months on four occasions (1941-42, 1946-47, 1956-57, and 1958-59), preventing the incorporation of the 'next year' in each case (shown by missing data points). The other three species did not flower every year (which is a common occurrence in eucalypts (Goodman, 1973)), and the lack of data points in these three graphs indicate the nonflowering years. Potential environmental factors (e.g. solar radiation intensity, soil moisture) which contribute to eucalypts failing to flower in some years are not well understood (House, 1997).

\subsection{Influences of temperature on flowering commencement date}

Table I shows that the influence of temperature was significant in two species only: E. leucoxylon and E. polyanthemos.

E. leucoxylon, which usually flowers in May in Maryborough, has $42 \%$ of the variation in its flowering commencement date accounted for by temperature. The addition of the regression coefficients indicates that the overall influence of the temperature is positive in this species. This suggests that, in response to a temperature increase, flowering would commence later: a shift of 21.1 days for an increase of $1{ }^{\circ} \mathrm{C}$. However, given that $58 \%$ of the variation in flowering commencement is unaccounted for, this figure should be viewed with caution. 

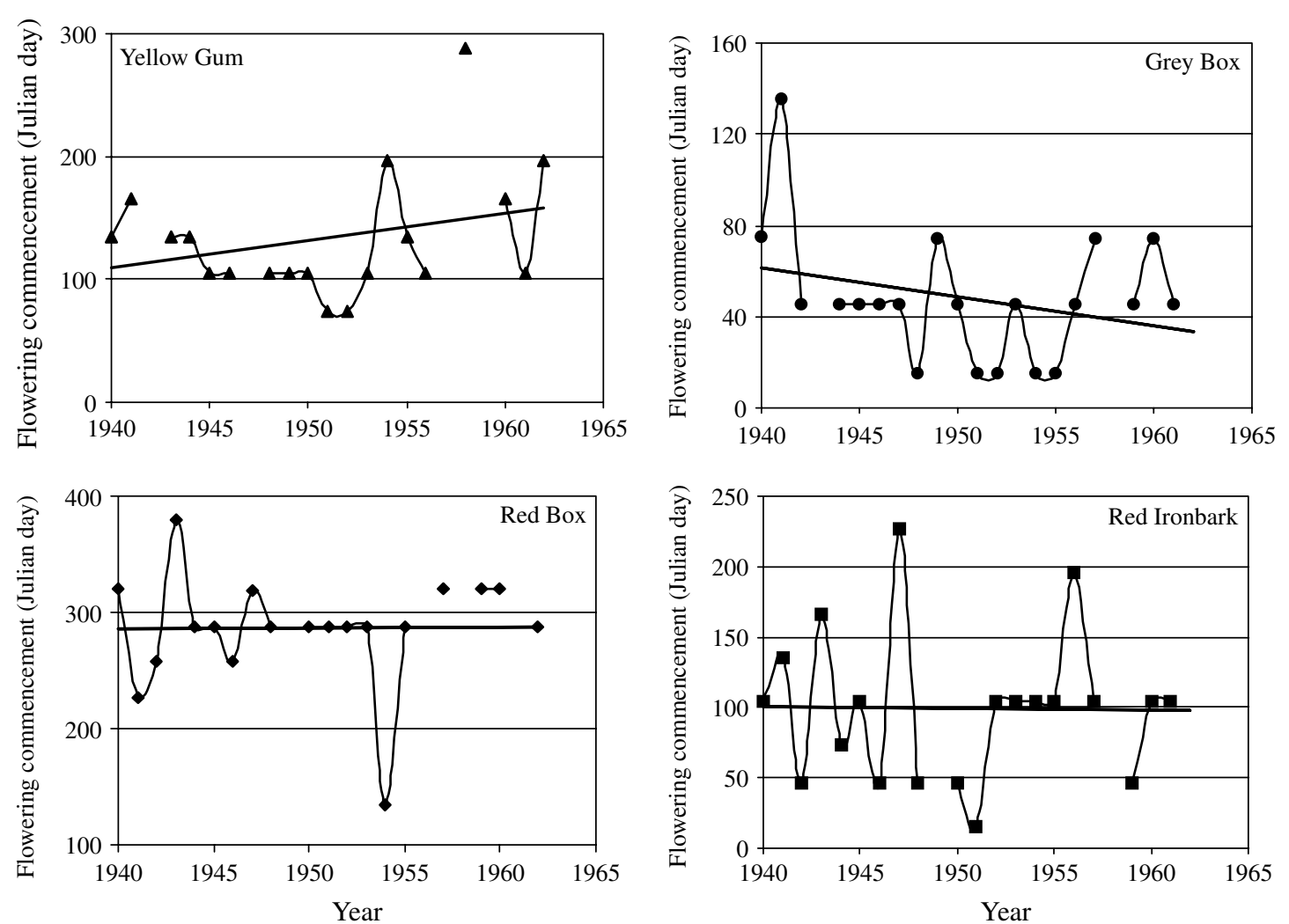

Figure 5. Julian flowering commencement date of yellow gum (E. leucoxylon), grey box (E. microcarpa), red box (E. polyanthemos) and red ironbark (E. tricarpa), in relation to time (1940-62). (Note: E. polyanthemos normally commences flowering around October. In 1944, E. polyanthemos did not commence flowering until 15 January, and hence its Julian day of commencement is recorded as 380 (i.e. $365+15$ days))

Table I. Stepwise regression coefficients for flowering commencement date (Julian days) in relation to temperature. Asterisks indicate the average month of flowering commencement (E. leucoxylon: YG; E. microcarpa: GB; E. polyanthemos: ReB; E. tricarpa: RIB)

\begin{tabular}{|c|c|c|c|c|c|c|c|c|c|c|c|c|c|c|c|}
\hline Species & Jan & $\mathrm{Feb}$ & Mar & Apr & May & Jun & Jul & Aug & Sept & Oct & Nov & Dec & $R^{2}$ & $P$ & $\begin{array}{l}\text { Shift }^{\mathrm{a}} \\
\text { (days) }\end{array}$ \\
\hline YG & & & & 20.3 & * & 29.1 & & & -28.3 & & & & 0.42 & $<0.01$ & 21.1 \\
\hline GB & & * & & & & & & & & & & & & NS & \\
\hline ReB & -19.2 & 28.9 & & -28.3 & & & & & -21.3 & $*$ & 20.1 & -13.2 & 0.47 & 0.02 & -33.0 \\
\hline RIB & & & & $*$ & & & & & & & & & & NS & \\
\hline
\end{tabular}

${ }^{\text {a }}$ Shift in flowering commencement date calculated per $1{ }^{\circ} \mathrm{C}$ in global temperature increase (Whetton et al., 1996).

E. polyanthemos, which commences flowering in the middle of the Australian spring, has $47 \%$ of its variation in commencement date explained by temperature. The months (November-February, April) found to be significant are concentrated in the warmer part of the year. The overall influence of temperature in this case is negative, indicating that an increase in temperature would result in flowering starting earlier by approximately 33 days. The same caveat, however, in relation to the amount of variation unaccounted for $(53 \%)$, applies here. 


\subsection{Influences of rainfall on flowering commencement date}

Table II illustrates that rainfall has a significant influence on E. leucoxylon and E. tricarpa (both of which commence flowering in autumn), as well as on E. polyanthemos. A greater proportion of the variation in flowering commencement is explained by rainfall in E. tricarpa (60\%), with increased rainfall delaying the onset of flowering. This would, however, result in a delay of only 0.4 days (as presented in 'Shift' column in Table II), assuming the 5\% increase in rainfall between November and April that is predicted for this region (Whetton et al., 1996). Given the assumed scenario of no change in winter half-year (May to October) rainfall, any significant relationships between flowering date and winter rainfall did not contribute to the predicted shift in flowering commencement. Both E. leucoxylon's and E. polyanthemos' relationship with rainfall is negative, accounting for $43 \%$ and $24 \%$ of the variation respectively. Therefore, these species would be expected to flower earlier, given the overall influence of all months (E. leucoxylon: 11.9 days; E. polyanthemos; 1.4 days). The influence of rainfall in individual months can, however, be opposing. For example, in E. leucoxylon, increased rainfall in January leads to later flowering, whilst increased rainfall in the other significant months leads to earlier flowering. In general, the rainfall-induced shifts in flowering commencement date are relatively small, given the assumed scenario of rainfall increasing only during the warmer half of the year (Whetton et al., 1996).

\subsection{Combined influence of temperature and rainfall on flowering commencement}

Table III indicates that flowering commencement in all four species is significantly influenced by the combination of temperature and rainfall. It also illustrates that the relationship between flowering commencement and these climatic variables is complex. For each species the variation explained by the combined influence of temperature and rainfall is greater than that explained by just temperature or rainfall alone, with the combined $R^{2}$ values ranging from 0.74 to 0.85 . Temperature, however, results in much greater shifts to flowering commencement date than does rainfall.

In both E. leucoxylon and E. tricarpa the influence of (increasing) temperature indicates a shift to later flowering. The influence of rainfall adds only marginally to this shift ( +0.7 days) to later flowering in E. tricarpa, and yields almost no change (+0.01 days) in E. leucoxylon. These shifts are based on the predicted $5 \%$ rainfall increase between November and April, with an unchanged rainfall for the remaining cooler months of year.

The overall shifts in flowering commencement indicated for E. leucoxylon and E. tricarpa are very large (70.6 days and 69.1 days respectively). These figures, however, must be considered against the wide variation observed in flowering commencement date for these species (133.7 \pm 51.3 and $99.4 \pm 53.1$ respectively). Wide variation in flowering commencement date is a well-reported trait of eucalypts (e.g. Ashton, 1956, 1975; Bassett, 1995; Pook, 1997).

Table II. Stepwise regression coefficients for flowering commencement in relation to rainfall. Asterisks indicate the average month of flowering commencement (E. leucoxylon: YG; E. microcarpa: GB; E. polyanthemos: ReB; E. tricarpa: RIB)

\begin{tabular}{|c|c|c|c|c|c|c|c|c|c|c|c|c|c|c|c|}
\hline Species & Jan & Feb & Mar & Apr & May & Jun & Jul & Aug & Sept & Oct & Nov & Dec & $R^{2}$ & $P$ & $\begin{array}{l}\text { Shift }{ }^{\mathrm{a}} \\
\text { (days) }\end{array}$ \\
\hline YG & 0.7 & -3.8 & -3.5 & & $-0.7^{*}$ & & -1.7 & & & & & & 0.43 & $<0.02$ & -11.9 \\
\hline GB & & * & & & & & & & & & & & & NS & \\
\hline $\operatorname{ReB}$ & -1.1 & & & & & & & & & $*$ & & & 0.24 & 0.02 & -1.4 \\
\hline RIB & & -0.9 & 1.4 & $*$ & 0.7 & 1.1 & & & -0.7 & -0.7 & & 1.7 & 0.60 & $<0.01$ & 0.4 \\
\hline
\end{tabular}

${ }^{a}$ Shift in flowering commencement date calculated from predicted 5\% increase in summer half-year (November-April) rainfall, per $1{ }^{\circ} \mathrm{C}$ increase in global temperature, with no change in winter half-year rainfall (Whetton et al., 1996). 
Table III. Stepwise regression coefficients for flowering commencement in relation to temperature (T) and rainfall (R). Asterisks indicate the average month of flowering commencement (E. leucoxylon: YG; E. microcarpa: GB; E. polyanthemos: ReB; E. tricarpa: RIB)

\begin{tabular}{|c|c|c|c|c|c|c|c|c|c|c|c|c|c|c|c|}
\hline Species & Jan & $\mathrm{Feb}$ & Mar & Apr & May & Jun & Jul & Aug & Sept & Oct & Nov & Dec & $R^{2}$ & $P$ & $\begin{array}{l}\text { Shift }^{\mathrm{a}} \\
\text { (days) }\end{array}$ \\
\hline YG T & 3.9 & & & 8.5 & $15.1^{*}$ & 43.7 & 49.6 & -50.2 & & & & & 0.79 & $<0.01$ & 70.6 \\
\hline $\mathrm{R}$ & 0.6 & -0.4 & & & & & -3.1 & & & & & & & & \\
\hline GB T & & * & & 37.0 & -62.9 & 58.0 & & -33.2 & & & & -42.1 & 0.84 & $<0.01$ & -41.4 \\
\hline $\mathrm{R}$ & 1.4 & -0.5 & 0.6 & & & -1.4 & & & -0.7 & & & & & & \\
\hline $\operatorname{ReB} T$ & & & 8.7 & -9.8 & & & & & & $-41.4^{*}$ & & & 0.74 & $<0.01$ & -43.8 \\
\hline $\mathrm{R}$ & -1.9 & 0.6 & & & & & & & & -1.1 & & & & & \\
\hline RIB T & 10.0 & & -7.4 & $24.1^{*}$ & & -45.5 & 69.9 & & & 17.3 & & & 0.85 & $<0.01$ & 69.1 \\
\hline $\mathrm{R}$ & & -1.0 & 0.8 & 0.7 & 0.3 & 2.2 & & & -2.9 & & & & & & \\
\hline
\end{tabular}

${ }^{a}$ Shift in flowering commencement date calculated per $1{ }^{\circ} \mathrm{C}$ global temperature increase, with corresponding $5 \%$ predicted increase in summer half-year (November-April) rainfall, and no change in winter half-year rainfall (Whetton et al., 1996).

An increase in global temperature of $1{ }^{\circ} \mathrm{C}$ would result in earlier flowering in E. microcarpa (41.4 days) and E. polyanthemos (43.8 days). Again, rainfall either adds slightly to (E. polyanthemos, -1.3 days) or reduces slightly this shift (E. microcarpa, +0.74 days).

\section{DISCUSSION AND CONCLUSIONS}

\subsection{Limitations of analyses}

These data were collected on a regular monthly basis, and hence there is a possibility that the observed flowering date may be up to a maximum of 30 days later than the actual date of commencement (i.e flowering may have commenced 'in between' two monthly observations). Interpretation of the predicted shifts in flowering date should take into account this sampling regime. Unfortunately, no long-term data of higher temporal resolution are known to be available within Australia.

The species studied here are found across different bioregions within southeastern Australia (Costermans, 1983), and hence the results outlined here may not be applicable elsewhere. Future work should aim to expand this analysis to other species and regions within Australia.

The available climate data are from a monitoring station in relatively close proximity $(3.5 \mathrm{~km})$ to the study site. Small-scale local variations in climate may have a minor impact on the observed relationships between climatic data and flowering commencement date.

As previously stated, Australian phenological records are very limited. The dataset used for this study, extending over 23 years, represents a good length record by Australian standards. Clearly, however, this type of analysis is most reliably undertaken with the longest data record possible.

\subsection{Implications of results}

Flowering commencement in E. leucoxylon, E. microcarpa, E. polyanthemos, and E. tricarpa did not show a statistically significant change over the relatively short study period (1940-62). Similarly, whilst there are observed increasing trends in temperature (Figure 3) and rainfall (Figure 4) over the period, neither are significant (regression $P=0.13$ and $P=0.07$ respectively). In examinations of growing seasons in Europe, which have tended to find an overall lengthening (Menzel and Fabian, 1999; Rötzer and Chmielewski, 2000), the trend is strongest from the 1980s (Rötzer and Chmielewski, 2000). In a future study, attempts will be made to incorporate extra data (from a second observer, between 1962 and 1978) from the study site (subject to successful calibration with the existing data), and from nearby sites, so that a longer period can be examined. 
Regardless of any trends over time, the results showed that flowering commencement in these species is significantly influenced by temperature, by rainfall, or by their combined effect. Therefore, changes in temperature and rainfall are likely to translate to changes in the timing of flowering commencement. The magnitude of possible shifts indicated are far greater than previously reported (Walkovszky, 1998; Ahas, 1999; Sparks et al., 2000; Menzel et al., 2001), although an advance of 38 days has been reported for yellowbellied marmots (Inouye et al., 2000). This difference is not surprising, however, given the large variation in flowering commencement date normally observed in these four eucalypt species.

When considered separately, temperature or rainfall has a significant influence on the flowering commencement of some species only (e.g. temperature was only associated with E. leucoxylon and E. polyanthemos). Previous studies (Porter, 1978; Keatley and Hudson, 2000) have found total rainfall over 2, 12 or 24 months prior to flowering in three of these species (E. leucoxylon, E. polyanthemos, and E. tricarpa) to be a poor predictor of flowering commencement date. The results presented in this paper suggest that it may be the rainfall in specific individual months (perhaps during the onset of an important phenophase) that accounts for the majority of variability in flowering commencement, rather than the total rainfall over defined periods. Overall, the influence of rainfall under the assumed climate change scenario was relatively minor, except in E. leucoxylon. E. microcarpa was the only species that was not significantly influenced by the individual consideration of either rainfall or temperature.

The combined effect of temperature and rainfall was found to be highly significant in all four species. In these relationships, temperature was the dominant influence. Therefore, given the predicted increases in temperature and rainfall, change in the flowering commencement of each of these species is likely. $E$. leucoxylon and E. tricarpa will commence flowering later, whereas E. microcarpa and E. polyanthemos will flower earlier.

The possible consequences of shifts in flowering commencement are, at this stage, supposition (Sparks et al., 2000). An intuitively expected effect, however, would be a change in pollination success, either through competition or facilitation. Reproductive success may also be further influenced by a shift in flowering commencement, as it seems that there is an optimal time (in terms of the success of seed development) for species to commence or cease flowering, depending on bud and fruit volume (Primack, 1987; Keatley and Hudson, 1998). In turn, these changes may ultimately result in a change to species composition with these forests, as the relative reproductive success of each species changes over time. Additionally, the presence and number of nectarivorous birds in southeastern Australian forests is closely aligned with the flowering intensity of these eucalypts (i.e. mass flowering attracts large numbers of nomadic nectarivorous birds) (McGoldrick and MacNally, 1998). Changes in flowering commencement are likely, therefore, to impact on the movement of birds across the landscape.

The differences in the significance of influence of the climatic variables on each species also has implications for which species should be chosen for future phenological monitoring in relation to climate change. Bio-indicators are usually chosen because they show a relationship between a phenological stage and a climatic variable, usually temperature (Walkovszky, 1998). The inherent variability in Eucalyptus flowering commencement date may preclude the use of many species as bio-indicators.

The selection of an appropriate indicator species should also consider the direction of any predicted changes in temperature and rainfall, and the subsequent predicted impact on flowering commencement date. It is preferable for flowering to be made consistently later (or earlier) by the predicted changes in both temperature and rainfall. Otherwise, the overall change in flowering commencement date may be confounded by opposing reactions to temperature and rainfall, although, with adequate data, these sub-components should be able to be delineated.

In the case of the species examined here, and for a region where temperature increases are predicted, along with increases in summer rainfall, E. polyanthemos would be the most suitable. It was the only species in which temperature and rainfall, singularly and combined, exerted their influence in the same direction.

The best overall prediction of flowering changes will be given by the examination of both temperature and rainfall. Given the greater individual influence of temperature, however, it may prove more cost-effective, and easier to interpret, if the relationship between temperature and flowering commencement is the primary focus of future monitoring. 


\subsection{Future directions for phenological studies in Australia}

The future for Australian phenological studies rests with the securing of the historical data and the establishment of a national phenological scheme.

Historical phenological records form part of our scientific memory (Keatley et al., 1999) and enable the determination of the behaviour of biological processes in the past, a crucial requirement for research into climate change impacts. Unfortunately, historical data are often undervalued by their custodians (the agencies who collected them) and are consequently lost (Walkovszky, 1998; Keatley et al., 1999; Sparks, 1999). There is an urgent need to safeguard against this. For research purposes, the historical data, which are in the written form, need to be digitized (Sparks, 1999). In this form, the data can be centralized and readily stored.

Currently, a search is being undertaken to determine whether the phenological data from other states in Australia have survived.

The historical data detail past behaviour, but the current, short-term phenological studies are only providing snapshots in time. In order to determine the nature and magnitude of the impact that climate change may have on ecosystems, continuous data provided by bio-indicators are required (Cannell et al., 1999). Consequently, there is a need for a national phenological monitoring programme, collecting data of adequate spatial and temporal resolution to build on the preliminary analyses presented in this paper. Canada (www.devonian.ualberta.ca/pwatch; Beaubien, 2001), the UK (www.phenology.org.uk; Attenborough, 2001) and The Netherlands (www.natuurkalender.nl; Hutten and van Vliet, 2001) have recently re-established (1995, 1998, and 2000 respectively) volunteer-based national schemes that provide models suitable for Australia.

Temperature and rainfall influence the flowering commencement of the species examined. Temperature, however, has the greatest influence. Therefore, predicted increases in temperature are likely to cause a shift in flowering commencement date. These shifts would be to later flowering in E. leucoxylon and E. tricarpa and to earlier flowering in E. microcarpa and E. polyanthemos.

E. polyanthemos would be suitable as a bio-indicator within a monitoring programme.

\section{ACKNOWLEDGEMENTS}

The School of Resource Management, University of Melbourne, provided infrastructure and financial support during the writing of this paper, as did the School of Science and Engineering, University of Ballarat. Thanks also to Leon Bren, Mark Stewart, John Petheram, Grigori Torgovnikov, Kathy van Oostveen, and Peter Vinden. Two anonymous reviewers provided valuable input to an earlier draft of this paper.

\section{REFERENCES}

Ahas R. 1999. Long-term phyto-, ornitho- and ichthyophenological time-series analysis in Estonia. International Journal of Biometeorology 42: 119-123.

Ashton DH. 1956. Studies on the autecology of Eucalyptus regnans. PhD Thesis, The University of Melbourne.

Ashton DH. 1975. Studies of flowering behaviour in Eucalyptus regnans F. Muell. Australian Journal of Botany 23: 399-411.

Attenborough J. 2001. Nature's calender [abstract]. In The Times They are A-Changin'. Climate Change, Phenological Responses and Their Consequences for Biodiversity, Agriculture, Forestry and Human Health, van Vliet AJH, den Dulk JA, de Groot RS (eds). Environmental Systems Analysis Group, Wageningen University: Wageningen; 59.

Bassett OD. 1995. Development of seed crop in Eucalyptus sieberi L. Johnson and E. globoidea Blakely in a lowland sclerophyll forest of East Gippsland. VSP Internal Report 26. Department of Conservation and Natural Resources: Victoria.

Beaubien EG. 2001. Plantwatch expands in Canada [abstract]. In The Times They are A-Changin'. Climate Change, Phenological Responses and Their Consequences for Biodiversity, Agriculture, Forestry and Human Health, van Vliet AJH, den Dulk JA, de Groot RS (eds). Environmental Systems Analysis Group, Wageningen University: Wageningen; 60.

Boland DJ, Brooker MIH, Chippendale GM, Hall N, Hyland BPM, Johnston RD, Kleinig DA, Turner JD. 1984. Forest Trees of Australia, 4th edn. Thomas Nelson: Australia.

Cannell MGR, Palutikof JP, Sparks TH (eds). 1999. Indicators of climate change in the United Kingdom. Department of Transport, Local Government and the Regions, London.

Chambers LT. 1893. The Colonial Beekeeper, 3rd edn. J.C. Stephens: Melbourne.

Costermans LF. 1983. Native Trees and Shrubs of South-eastern Australia. Weldon Publishing: Sydney.

CSIRO. 2001. Climate Change Projections for Australia. Climate Impact Group, CSIRO Atmospheric Research: Melbourne.

Davis GL. 1969. Floral morphology and the development of the gametophytes in Eucalyptus stellulata SIEB. Australian Journal of Botany 17: 177-190.

Findlay STG, Jones CG. 1989. How can we improve the reception of long-term studies in ecology? In Long-term Studies in Ecology: Approaches and Alternatives, Likens GE (ed.). Springer-Verlag: New York; 201-202. 
Goodman RD. 1973. Honey Flora of Victoria. Department of Agriculture: Melbourne.

House SM. 1997. Reproductive biology of eucalypts. In Eucalypt Ecology: Individuals to Ecosystems, Williams JE, Woinarski J (eds). Cambridge University Press: Cambridge; 30-55.

Hutten SCM, van Vliet AJH. 2001. A new phenological monitoring scheme in the Netherlands: De Natuurkalender [abstract]. In The Times They are A-Changin'. Climate Change, Phenological Responses and their Consequences for Biodiversity, Agriculture, Forestry and Human Health, van Vliet AJH, den Dulk JA, de Groot RS (eds). Environmental Systems Analysis Group, Wageningen University: Wageningen; 62.

Inouye DW, Barr B, Armitage KB, Inouye BD. 2000. Climate change is affecting altitudinal migrants and hibernating species. Proceedings of the National Academy of Sciences 97: 1630-1633.

IPCC. 2001a. Summary for Policymakers. A Report of Working Group 1 of the Intergovernmental Panel on Climate Change. IPCC: Shanghai.

IPCC. 2001b. Summary for Policymakers. Climate Change 2001: Impacts, Adaptation, and Vulnerability. A Report of Working Group II of the Intergovernmental Panel on Climate Change. IPCC: Geneva.

Keatley MR. 1999. The flowering phenology of box-ironbark eucalypts in the Maryborough region, Victoria. Ph.D Thesis, The University of Melbourne.

Keatley MR, Hudson IL. 1998. The influence of fruit and bud volumes on eucalypt flowering: an exploratory analysis. Australian Journal of Botany 42: 281-304.

Keatley MR, Hudson IL. 2000. Influences on the flowering phenology of three eucalypts. In Biometeorology and Urban Climatology at the Turn of the Century. Selected Papers from the Conference ICB-ICUC' 99, de Dear RJ, Kalma JD, Oke TR, Aucliems A (eds). World Meteorological Organisation: Geneva, Switzerland; 191-196.

Keatley MR, Hudson IL, Fletcher TD. 1999. The use of long-term records for describing flowering behaviour: a case-study in Victorian box-ironbark forests. In Australia's Ever-changing Forests IV, Dargavel J, Wasser B (eds). Australian University Press: Canberra; $311-328$.

Koch E. 2000. Phenology in Austria: phenological mapping - long-term trends. In Biometeorology and Urban Climatology at the Turn of the Century. Selected Papers from the Conference ICB-ICUC' 99, de Dear RJ, Kalma JD, Oke TR, Aucliems A (eds). World Meteorological Organisation: Geneva, Switzerland; 187-190.

Law B, Mackowski L, Tweedie T. 2000. Flowering phenology of myrtaceous trees and their relation to climate, environmental and disturbance variables in northern New South Wales. Austral Ecology 25: 160-178.

Leith H. 1974. Purposes of a phenology book. In Phenology and Seasonality Modeling, vol. 8, Leith H (ed.). Springer-Verlag: New York; 3-19.

Loneragan OW. 1979. Karri (Eucalyptus diversicolor F. Muell.) phenological studies in relation to reforestation. Bulletin 90. Forest Department of Western Australia: Perth.

Manning M, Nobre C (eds). 2001. Technical Summary Climate Change 2001: Impacts, Adaptation, and Vulnerability. Intergovernmental Panel on Climate Change: Geneva.

McGoldrick JM, MacNally R. 1998. Impact of flowering on bird community dynamics in some central Victorian eucalypt forests. Ecological Research 13: 125-139.

McLachlan RG. 1909. Grampians district eucalypts. The Federal Independent Beekeeper: 6-8.

McLachlan RG. 1921. Victoria Valley experiences. The Victorian Bee Journal 2: 64-65.

Menzel A, Fabian P. 1999. Growing season extended in Europe. Nature 397: 659.

Menzel A, Estrella N, Fabian P. 2001. Spatial and temporal variability of the phenological seasons in Germany from 1951 to 1996. Global Change Biology 7: 657-666.

Moncur MW, Boland DJ. 1989. Floral morphology of Eucalyptus melliodora A. Cunn ex. Schau. and comparisons with other eucalypt species. Australian Journal of Botany 37: 125-135.

Muir AM, Edwards SA, Dickins MJ. 1995. Description and conservation status of the vegetation of the Box-Ironbark ecosystem in Victoria. Flora and Fauna Technical Report 136. Department of Conservation and Natural Resources, Melbourne.

Pook EW. 1997. Long-term variation of litter fall, canopy leaf area and flowering in a Eucalyptus maculata forest on the south coast of New South Wales. Australian Journal of Botany 45: 737-755.

Porter JW. 1978. Relationships between flowering and honey production of red ironbark, Eucalyptus sideroxylon (A. Cunn.) Benth., and climate in the Bendigo district of Victoria. Australian Journal of Agricultural Research 29: 815-829.

Primack RB. 1987. Relationship among flowers, fruits and seeds. Annual Review of Ecology and Systematics 18: 409-430.

Rötzer T, Chmielewski F-M. 2000. The international phenological gardens - 40 years of observation. In Biometeorology and Urban Climatology at the Turn of the Century. Selected Papers from the Conference ICB-ICUC' 99, de Dear RJ, Kalma JD, Oke TR, Aucliems A (eds). World Meteorological Organisation: Geneva, Switzerland; 181-186.

Sagarin R, Micheli F. 2001. Climate change in non-traditional data sets. Science 294: 811.

Schwartz MD. 2000. Networking with satellites: perspectives on the future of phenology. In Biometeorology and Urban Climatology at the Turn of the Century. Selected Papers from the Conference ICB-ICUC' 99, de Dear RJ, Kalma JD, Oke TR, Aucliems A (eds). World Meteorological Organisation: Geneva, Switzerland; 169-174.

Snyder RL, Spano D, Duce P, Cesaraccio C. 2001. Temperature for phenological models. International Journal of Biometeorology 45: $178-183$.

Sparks TH. 1999. Phenology and the changing pattern of bird migration in Britain. International Journal of Biometeorology 42: $134-138$.

Sparks TH, Carey PD. 1995. The responses of species to climate over two centuries: an analysis of the Marshman phenological record, 1736-1947. Journal of Ecology 83: 321-329.

Sparks TH, Jeffree EP, Jeffree CE. 2000. An examination of the relationship between flowering times and temperature at the national scale using long-term phenological records from the UK. International Journal of Biometeorology 44: 82-87.

Walkovszky A. 1998. Changes in phenology of the locust tree (Robinia pseudoacacia L.) in Hungary. International Journal of Biometeorology 41: 155-160.

Wang QJ, Chiew FHS, McConachy JS, de Hoedt GC, Wright WJ. 2001. Climatic Atlas of Australian Evapotranspiration. Bureau of Meteorology and CRC for Catchment Hydrology: Melbourne. 
Wells K. 2000. Long term cyclic and environmentally induced effects on flowering of four box-ironbark eucalypts. Fourth Year Project Thesis, University of Melbourne, Parkville.

Whetton P, Mullan BA, Pittock AB. 1996. Climate-change scenarios for Australia and New Zealand. In Greenhouse: Coping with Climate Change, Bouma WJ, Pearman GI, Manning MR (eds). CSIRO Publishing: Melbourne; 145-168.

Whitfield J. 2001. Climate change data: the budding amateurs. Nature 414: 578-579. 